\author{
$@ \oplus \Theta$ \\ Jurnal Terapan Manajemen dan Bisnis is licensed under \\ A Creative Commons Attribution-Non Commercial 4.0 International License.
}

\title{
ATTITUDE AS A VARIABLE BETWEEN THE EFFECT OF SECURITY, CLEANLINESS AND PUBLIC FACILITIES ON DOMICILE DECISIONS IN SATELIT CITY OF SIDOARJO DISTRICT
}

\author{
Abdul Halik \\ University of August 17, 1945, Surabaya, Indonesia \\ E-mail: haliksurabaya@gmail.com
}

\begin{abstract}
Satelit city has populations mostly working in metropolitan cities. Migration from metropolitan cities to Satelit city due to the land use reduction and the house purchasing power has increased, while the residence needs are very important. Workers in metropolitan cities drive off through traffic jam. Students go to metropolitan cities from the Satelit city looking for better education facilities. The population density in Satelit city is caused by migration from metropolitan cities. Migration is the occurrence of sub-urbanization phenomena in a Satelit city around the city of Surabaya. The development of Satelit city is very dynamic and making people try to find a more comfortable place and friendly neighborhood. Property developers have provided the concept of a convincing residence which is conducive, clean and safe so that the decision to domicile to live in Satelit city more commodious.
\end{abstract}

The security of a city influences a person's attitude in determining a place to live. A safe environment will make residents save. Security of family, wealth and place is a necessity that must be fulfilled in order to live a happy life. Moreover, the aspect that influences the attitude of people's domicile decisions is the cleanliness of the city. Cleanliness is related to the elements of health, pollution, and odor, so as the ideal place to live in is a place which is free from all factors that interfere with human health. Many developers organize neatly locations, a human lifestyle based on the rules of the developers, so that cleanliness can be controlled properly. With adequate facilities, residents will stay in Satelit city and not go to big cities. Public facilities will strengthen the attitude of a person to live in a Satelit city if the needs of citizens are fulfilled. The sense of security that is needed for the residents is the security of the neighborhood in which they live in because each person realizes that security is often unexpectedly disturbed. The cleanliness aspect is not an absolute requirement, because the clean and beautiful city is common. Deciding to stay in a place, the public facilities need to be seriously considered, because every person has the pretension to live and settle down.

As a result of the data analysis and discussion on various variables and indicators, the researcher suggests that (a) for domiciles in Satelit city, someone must consider the public facilities available. Many elements become alternatives for them and can ensure that forming a family is more comfortable and saver (b) developers can provide residences accordance with purchasing power and setting security, cleanliness, and facilities as well as those needed by residents. A sense of security, cleanliness and reachable facilities will strengthen a person's decision to choose to live in a certain area. 
Keywords: Security; Cleanliness; Public Facilities; Attitude; Domicile Decision

\section{Introduction}

The development of a metropolitan city will have a good impact on the nearest city. Satelit city is a buffer area which the population mostly works in the metropolis and reside in Satelit city such as Sidoarjo District. Migration from metropolitan cities to buffer area due to the land use reduction and the house purchasing power has increased, while the residence needs are very important. The phenomenon that occurs is the expansion of the population, property developers and housing demand in developing countries where Satelit city serve as a buffer area for metropolitan cities (Merrilees, Miller and Herington, 2013). Employees can go to work in metropolitan using public or private vehicles through the congested traffic and go back to the Satelit city. For students from Satelit city learn in the metropolis because of its adequate education facilities. Otherwise, there are also students who study in a Satelit city, because many schools have facilities as equivalent to metropolitan cities. The existence of people needs and the timeline, the Satelit city and the population can grow rapidly because of its densely.

The city of Surabaya is a famous city in East Java and neighboring to Sidoarjo, Gresik, Bangkalan, Mojokerto, and others. One aspect that causing population density in Satelit city is migration from metropolitan cities. Migration is its happening suburbanization phenomenon in buffer area around the Surabaya. The development of a buffer city is very dynamic makes people try to find a more comfortable place and environmentally friendly conditions. Property developers should provide a concept of residential space that is suitable as the metropolitan city, conducive, clean and safe so that the residences attitude to life in Satelit city are very large.

The more densely populated in the buffer area will be more competition, and it seemed to be emerging problems related to environmental, economic, social, etc. The increasing population in Satelit city will have an impact on increasing unemployment and crime due to intense competition. To measure the stress level of a city where the factors are the unemployment rate, work period, crime and divorce rates (Sperling, 2010). Creating a well-known city in the process of forming a brand from one city to make it easier for residents or the city government to introduce it to the markets such as investors and tourists. To reduce crime and unemployment level, a city needs to synergize with investors from any field so that city problems can be reduced.

The Sidoarjo area has emerged elite settlements that continue to develop modern infrastructure such as the Ramayana Mall, apartments and star rated hotels. Sidoarjo District, which is located directly on the border to Surabaya City, so that residents in the border area being live in the metropolitan area. The public facilities in Surabaya City are even located in the land of Sidoarjo such as the bus station of Bungurasih. Residence developers are interested in Sidoarjo especially at the border area and had created a wide two-way road so as to make accessible way and built a Water Park and iconic town square and it makes Sidoarjo district as the new economic center in any residential area of Sidoarjo district. The Satelit city continues to build more infrastructure so that between sub-districts and Sidoarjo are well connected so that industrial estates can develop well and can increase local revenue. A city can develop rapidly if the local revenue rises steadily and is used for the welfare of the people of Sidoarjo.

This study adopts Merrilees et al. (2013) about Brand Association Model where this model focuses on 3 attributes that exist in the city, namely, Clean Environment, Safety, and Government Services. There are nine variables displayed in the Brand Association Model, the researchers only used three variables that were in accordance with the current phenomenon. 
The aspect of security, cleanliness, and facilities is a strong correlation and an important influence in determining an ideal place to live in order to build a happy and healthy domicile. Human behavior is strongly influenced elements that make people so comfortable, quiet and clean so that people will take the decision to by living in a region.

\section{Literature Review}

A. Marketing Management

Marketing management is one of the main activities carried out by the company to maintain the continuity of the company, to develop, and to obtain credit (Dharmmesta \& Handoko, 2008 ). The marketing process began long before the items were produced, and did not end with sales. The company's marketing activities must also give satisfaction to consumers if they want their business to continue, or consumers have a better view of the company. Dharmmesta and Irawan (2008) said that marketing management is analyzing, planning, implementing and monitoring programs aimed at exchanging with the intended market with the aim of achieving organizational goals. According to Kotler and Keller (2013), marketing management is as an art and science of selecting target markets and reaching, maintaining and growing customers by creating, delivering and communicating superior customer value. Developers must understand the needs of urbanites regarding the quality of houses, prices and the neighborhood including security, cleanliness and public facilities which are inseparable integration. Satelit city as buffer cities for metropolis must be able to provide the needs of citizens.

It can be concluded that marketing management is a management process carried out by the company, in order to survive through the activities of transactions with other parties and give satisfaction to their needs and pretension.

\section{B. Marketing Mix}

According to Kotler and Armstrong (2008), the marketing mix is a series of marketing tools that can be controlled, which included the product, price, place (distribution), and promotion to the mix by companies in order to give the expected response by companies in achieving market targets. The definition of the marketing mix (Kotler, 2007) is a combination of four variables or activities which are the core of the marketing system, namely products, prices, distribution, and promotion. Developers property must prepare the residences according to the purchasing power of the population and the distribution of suitable land. Implement pricing policies that are easily accessible to buyers and carry out appropriate promotional functions so that consumers quickly understand such as sales promotions, exhibitions, and advertisements. The developer needs to convey information about the concepts of security, cleanliness and public facilities that will be provided.

In conclusion, the marketing mix is a collection of variables that can be used by a company to influence consumers. The marketing mix is to strengthen and improve the response to the marketing elements, resulting in a transaction between supply and demand is to the purpose of the company.

\section{Consumer Behavior}

According to Engel et al. (2004), consumer behavior is an action that is directly involved in acquiring, consuming, and spend products, and services, including the process of decisions that precede and follow this action. Consumer behavior is a human activity that is directly involved in being able to use and use products and services in the decision-making process. There are two elements of the decision-making processes and activities in physical form by involving personnel for research, obtaining and using products and services 
economically. There are five major elements of consumer behavior: (1) the amount of purchase by consumers (2) processes transactions between businesses and consumers (3) the company market strategies (4) how to meet human needs (5) conducive situation of the business environment. Overall, the principle of consumer behavior can be implemented well towards marketing business with business or marketing business with consumers.

The more advanced information technology and economy that followed the competition to meet the needs, the sales strategy developers must be run fairly and accurately. To increase sales, the developers need to understand consumer behavior with regard to the purchase of the house and determine the size of houses required. Consumers always consider the price and size of house services. For this reason, it is necessary to pay attention to consumer behavior that always changes. The decision to buy a house as a place to live for consumers, then the understanding of developers on consumer behavior need to be considered. The behavior of the residents in deciding to stay need a lot of consideration, such as security, cleanliness and public facilities, because the three aspects are very relevant in building a residence. Everyone always chooses a place to live that can be efficient and productive in their lives.

In conclusion, consumer behavior is an individual or mutual decision-making process that be directly in the plan, search, rate, use and buy products or services, for their needs that must be fulfilled. In the decision process the role of information about marketing elements, it takes consumers to know so as a reference in deciding to buy it. The modern era of consumers always considers the elements of efficiency and effectiveness in using products or services, so online sales are often an option in the process of getting products.

\section{Security}

According to Tarwoto and Wartonah (2010) that security is a safe and secure state. Humans in their lives need calm, safe and protected physically and mentally so that they can carry out normal activities. The productivity of individuals and organizations depends on security at that location. Safety does not prevent pain but can make individuals safe in carrying out activities and reducing stress. The basic principle of security is according to the human ability to avoid the threat. Knowledge, awareness, and motivation of people in taking preventive actions, so that there will be no threat. There are three aspects to security, namely the level of individual knowledge and awareness, physical and mental abilities to make preventative efforts, and the physical environment that is harmful or potentially dangerous.

Security has a strategic role in forming brand attitude because people want to stay if security is guaranteed. Security elements can be formed by citizens, community groups and the government because collaboration will occur mutual understanding that safety is important in a district. Security for residents can influence comfort while living in a city, such as a buffer city close to adequate facilities and close to a metropolitan city. Security around the residence is a personal responsibility, but the residents should prepare a security unit so that security can be guaranteed. A safe settlement will create satisfaction for the local residents because it can carry out activities calmly and safely. Security is a sense of safety from disease outbreaks, natural disasters, fraud, political and social strife, the risk of traffic accidents, and crime. The principle of security in the area affects the freedom and comfort of residents currently living in the region and facilitate the people to achieve prosperity.

Security has a positive influence and relationship on the City Brand attitude so that cities that are considered safer will get a City rating that has a more positive brand attitude from the people (Merrilees et al., 2009). Security can have an effect on the attitude of the people who will or are already domiciled in Satelit city because stakeholders always create a sense of security and protect the residents so that they can live in peace and work optimally 
to meet their daily needs. Security in general in the regions is the responsibility of the state, but the participation of the people is needed to maintain regional conduciveness both from the elements of violence and crime.

It was concluded that security is the process of maintaining peace and security both physically and mentally for the people. In a safe environment, people can live in peace and naturally without fear and danger. A safe area will be able to develop the economy, increase income and be easy to achieve prosperity. Creating security cannot be done independently but must be through cooperation between the people and the security authorities in the country of Indonesia such as the police, security guards and the people itself.

\section{E. Cleanliness}

Everyone strives to maintain cleanliness, especially in the family environment. Cleanliness is a human attempt to take care of an environment of all dirty and soiled objects in order to create and sustain the environment comfortable and healthy. Cleanliness is a requirement to create health for every human being. Healthy is one aspect that can give happiness. However, dirty would spoil the beauty and can lead to various diseases resulting in suffering for humans. Keeping clean means creating health for yourself and others.

Cleanliness is a reflection for each individual to maintain very important and expensive health in human life. Environmental hygiene is a condition free from any dirt and diseases, which can affect all element that related to activity and behavior of people in an area, human life can not be separated to the natural environment and social environment. Cleanliness is the main aspect to create health in the form of human rights and welfare aspects that must be realized in accordance with the ideals of the Indonesian people. According to regulations No. 36 of 2009 concerning health which states that the highest degree of public health through the implementation of health development cannot be separated from problems that are closely related to cleanliness.

The clean environment attribute refers to the physical conditions of the environment which are assessed from aspects of physical cleanliness and pollution-free air (Merrilees et al., 2009). Hygiene indicators which include the physical environment, clean air, and free pulses, so that it will become a guideline for residents who will domicile in a city such as a Satelit city. Guidelines for choosing a place to live must think comprehensively of pollution-free elements and air quality that is compatible with human beings. The priority of the main aspects in deciding on domicile is a basic consideration, so as not to experience disappointment in the future.

The environment is a condition that affects the development and behavior of human beings. All surrounds to humans could affect the development of human life, either directly or indirectly. Environmental properties in the form of (1) types of elements that build the environment (2) relations between aspects of the environment (3) conditions of environmental elements (4) non-material factors such as temperature, light, and noise. Some of these factors can determine the quality of the environment. The opinion of Merilees et al. (2009) found that a clean environment has a positive influence on a brand attitude. Residents of Satelit city considered the city getting clean, it will have an increasingly positive brand attitude to the Satelit city. So that the value of a clean environment plays an important role in forming a brand attitude of a city.

In conclusion, cleanliness is a process of keeping from the elements that cause people to become sick and make them comfortable for humans. A dirty place will bring disease viruses, both from air, animals, and odors. Cleanliness is the beginning of one's health, being the responsibility of all components of the nation and especially the government. 


\section{F. Public Facilities}

According to A.S. Moenir A (2002) stated that the process of fulfilling needs through the activities of other direct people was called service. Service is an activity that aims to help prepare what others need so that activities can be carried out. Service is an activity that is perceived through the interaction between the recipient and the service provider using equipment such as an organization with clear and complete rules. Public facilities are all forms of services provided in the form of public goods and public services are responsible and implemented by the government in order to implement the provisions of the applicable laws and regulations. According to Nana Syaodih (2009) states that learning facilities are all that is needed in the learning process both mobile and immovable in order to achieve educational goals running smoothly, regularly, effectively and efficiently.

All learning infrastructure facilities are a necessary facility for students in achieving learning goals through learning activities in the form of investigations and discoveries to gain an understanding of the problems being studied. Public facilities for all facilities provided by the local government at a cost from the government budget. Health development is an effort to fulfill one of the basic rights of the people accessed by health service facilities because health is human rights.

Government Service is an element that is in a town which includes the provision of facilities to meet the needs of people's education, health, and infrastructure. The goal is to provide services, namely to improve people's welfare. An aspect that can influence the perception of the community on the image of a city such as the Satelit city of Sidoarjo District. Government services have a positive influence on city brand attitude that the people consider that the services provided by the government are adequate in a city, so they will have a City Value that has a more positive attitude towards the city (Merrilees et al., 2009). Values of government services through public facilities play an important role in brand attitude formation, so that will make people want to reside in the city.

Conclusions that public service is the provision of facilities and infrastructure by the government and the costs and needs of the people that cannot be provided independently. The aim is to help the difficulties of the population in carrying out activities to meet needs both individually and publicly. The people must comply with applicable regulations issued by the local government so that the use of facilities can be guaranteed.

\section{G. Consumer attitude}

Attitude is an evaluative statement of an object, person or event and reflects a person's feelings for something. Attitudes can be generated from my knowledge but attitudes are not the same as behavior. According to Fishbein (2006) Attitude is an emotional predisposition that is learned to respond consistently to an object. Elements of attitudes need to be considered in order to help marketers to adjust the message conveyed to the community. According to Secord and Backman (2012), Attitudes are certain regularities in terms of feelings (affections), thoughts (cognitive), and predisposing actions of someone to an aspect in the surrounding environment. A general evaluation made by humans on themselves or others for reactions or responses to objects that give rise to feelings by acting according to the object.

City Brand Attitude is the attitude of the population towards city brands wherein there is an assessment of lifestyle, reputation, and pride because of living in a particular city (Merrilees et al., 2009). The attitude of the population towards the city brand is influenced by many factors where there are only a few factors that are really significant in giving influence. In city brand attitude there is an attribute of resident satisfaction which is an indicator of the environmental quality of the population. Intention to living will measure the extent of the 
intention of the population to want to live in a city including the intention to retire and settle in the city (Merrilees et al., 2013).

In conclusion that attitude is an evaluative process on objects that starts from stimuli that are perceived by the human senses. Action will be carried out by humans, if the attitude experiences a positive tendency and vice versa if the negative values are more dominant, then people will ignore the object. Messages received by humans get complete and accurate information so that humans have the material to decide properly and correctly.

\section{H. Consumer Decision}

According to Stoner (1996), decision making is describing the process used to choose an action as a way of solving problems. Decision making is the process of selecting one of several alternative problems solving available. Consumer behavior is a study that needs to be carried out by the company and every stage must be passed because no human being directly takes action without the previous process. The decision-making process is more focused on the typical consumer than its products.

Consumer behavior always determines the decision-making process of buying decisions. According to (Kotler, 2005) process is a problem-solving approach that consists of analyzing the needs, assess the source, goal, identify purchasing alternative and buying decisions. One way how to make decisions are based on the intuition take a short time and a certain problem. Intuitive decision making will give satisfaction, but the results of this decision are difficult to measure.

Decision-making purposes is an activity carried out within the organization to achieve organizational goals. For this reason, obstacles often occur in carrying out activities, because the problem is solved by the leadership of the organization. Decision making can be done individually if the nature and characteristics of the problem can be done privately.

In conclusion, decision making is a process of solving the problems with envoy right, true and rational decision. Every decision taken is very decisive in running an organization. If the decision is incorrect, then the organization's problems will be unsolved whereas if the decisions are correct, then the problems in the organization will be completed properly and the organization will certainly run well and be able to maintain sustainability.

\section{Research Methods}

\section{A. Research design}

The research design is a plan, a framework for conceptual relation structure of variables in a study (Kerlinger, 1990 ). According to Aaker and Day (2001), a research design is detailed planning is used as a guideline for research studies that lead to the objectives of the study. This research design intends explained between variables that have an influence and testing hypotheses and perform explanation on other variables so that the design of this research is explanatory research.

\section{B. Population and Samples}

The population is something that is a certain quantity and characteristic. The population to be studied needs to be chosen based on the ideal number of samples in this study. The intended population is immigrants who live in Sidoarjo District. The researcher set a sample of 200 respondents. Respondents are citizens who are selected according to the conditions stipulated for this study and easily found both at home and in other places, it is used as respondents who have knowledge regarding Sidoarjo District. 
C. Sample and Measurement Techniques

The method is used in this study is sampling Purposive, is a technique of determining samples with certain considerations. Researchers use it in taking samples of the purposive sampling by selecting residents, according to the needs of respondents who have been assigned and can be found either at home or anywhere else there is used as the respondent.

The measurement scale is to use agreement as a reference to determine the length of the interval as a measuring instrument so that the measuring instrument when used in the measurement will produce quantitative data (Sugiyono, 2010). Use a Likert to measure attitudes, opinions, and perceptions of someone or a group of people regarding social phenomena.

\section{Data Collection Techniques}

The procedure for collecting data in this study with stages starting from designing the questionnaire and delivering the questionnaire to the target respondents. Using the primary and secondary data as follows:

Primary is data obtained directly from respondents by researchers is the result of questionnaires distributed to respondents that migrants who live in Sidoarjo.

The secondary is data available in the relevant institutions with the object of research, secondary data can be derived from the library, reports, internet and etc.

\section{E. Technique Analysis Data}

This research is a multidimensional study, meaning that the practical phenomenon can be expressed in several indicators. For the answer, analysis is obtained from the respondent's answer and then input into the data used for Structural Equation Modelling (SEM) version of AMOS 22 as a tool to answer various existing variables.

\section{Results and Discussion}

A. Results of Data Analysis Descriptions

1. Profile of respondents

The respondents used in this study were 200 respondents and residents domiciled in Sidoarjo District in Table 1.

Table 1 Profile of respondents

\begin{tabular}{|c|c|c|}
\hline Description & Frequency & $\%$ \\
\hline \multicolumn{3}{|l|}{ Gender: } \\
\hline Man & 90 & 45 \\
\hline Woman & 110 & 55 \\
\hline Total & 200 & 100 \\
\hline \multicolumn{3}{|l|}{ Age: } \\
\hline 17 years -25 years & 48 & 24 \\
\hline 26 years - 35 years & 97 & 49 \\
\hline 36 years - 45 years & 45 & 22 \\
\hline 46 years - 55 years & 6 & 3 \\
\hline$\geq 56$ years & 4 & 2 \\
\hline Total & 200 & 100 \\
\hline \multicolumn{3}{|l|}{ Education: } \\
\hline Graduated from high school & 61 & 30.5 \\
\hline Graduated Diploma (D-1, D-2, D-3) & 30 & 15 \\
\hline Graduated Bachelor (S-1, S-2, S-3) & 109 & 54.5 \\
\hline Total & 200 & 100 \\
\hline $\begin{array}{l}\text { Job : } \\
\text { Civil Servant / Army / Police }\end{array}$ & 28 & 14 \\
\hline
\end{tabular}




\begin{tabular}{lcc}
\hline \multicolumn{1}{c}{ Description } & Frequency & \% \\
\hline Entrepreneurship & 37 & 18.5 \\
Private employees & 96 & 48 \\
Student & 39 & 19.5 \\
\hline \multicolumn{1}{c}{ Total } & 200 & 100 \\
\hline Expenditures : & 33 & 16.5 \\
<Rp.1.5 00,000 & 83 & 41.5 \\
Rp.1.600,000 to Rp.2,000,000 & 56 & 28 \\
Rp.2,000,000 to Rp.3,000,000 & 28 & 14 \\
> Rp. 3,000,000 Total & 200 & 100 \\
\hline \multicolumn{2}{c}{ Tot }
\end{tabular}

2. Validity and Reliability

a. Validity test

Validity test is to test items (statements). Validity test to measure whether the measuring instrument used is valid or invalid. Validity test in this study the author uses SPSS V.22 software. Test item validity is a valid item (statement) if it has strong support for the total score. To fit the validity requirements, the questions in the study must have a correlation coefficient $(r)>0.30$, and if the correlation between items is a total score $<0.30$, then the items in the questionnaire are declared invalid (Sugiyono, 2010). If the validity of all items of the indicator meets the validity requirements, because the item statement in the study must have a correlation coefficient $(r)>0.30$, and if the correlation between items is a total score $<0.30$, then the item statement in the questionnaire is declared invalid.

To test construct validity, the conditions that must be fitted, first the loading factor must be significant. Because significant loading factors may still be of low value, the standardized loading estimate must be equal to 0.50 or more and ideally, it should be 0.70 (Ghozali, 2013). The results of the loading factor values of each indicator can confirm the variables well. It can be concluded that the empirical data used is in accordance with the variable framework. The cut of value used to test the significance of factor weights is loading factor $\geq 0.5$ or critical ratio $>2.0$ because significant indicators are dimensions of latent variables formed.

\section{b. Reliability Test}

In order to test the instrument internal consistency is indicated by the Alpha Cronbach coefficient $>0.6$, then the question is stated to be reliable (Nunally) in (Ghazali; 2013 ). all indicators of each variable calculated by the Alpha Cronbach coefficient are all indicators above 0.6 , meaning all variables used are said to be reliable. The criteria used are if the construct reliability $>0.70$ indicates good or reliable reliability, while the reliability of 0.60 - 0.70 can still be accepted on the condition that the validity of indicators in the capital is good (Ghozali, 2013). The results of the reliability values of all constructs are greater than 0.70 means that all indicators of exogenous and endogenous variables are reliable.

\section{c. Data Analysis}

The test results use structural equation modeling. To produce a fit model, it is necessary to do modification indices, according to the facilities in SEM, the results of the modification can be seen in Fig. 1.

The model is acceptable, even though the evaluation of the criteria for Goodness of Fit Indices for all the criteria required has met and is appropriate, good. To test the hypothesis of a causal relationship between security variables, cleaning, public facilities on attitudes and decisions of domicile in Satelit city. The results of the path coefficient of the causal relationship between the variables in this study can be seen in Table 2 . 


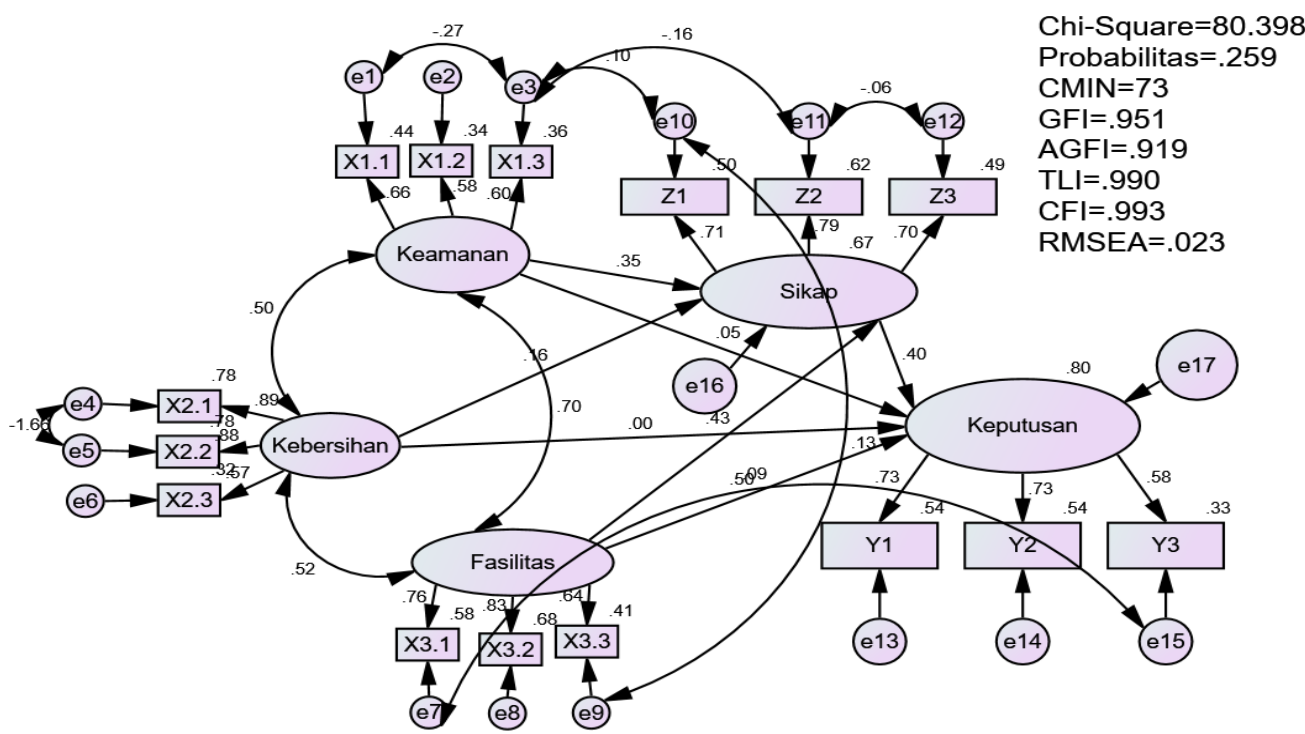

Fig. 1 Structural Equation Modeling

Table 2 Path Coefficient (Standard Regression) Relation Between Variables

\begin{tabular}{clcccc}
\hline No. & \multicolumn{1}{c}{ Variables } & $\begin{array}{c}\text { Path } \\
\text { Coefficient }\end{array}$ & $\begin{array}{c}\text { Critical } \\
\text { Ratio }\end{array}$ & Probability & Result \\
\hline 1 & Domicile Attitude $\leftarrow$ Security & 0,423 & 2,277 & 0,023 & Significant \\
2 & Domicile Attitude $\leftarrow$ Cleanliness & 0,189 & 2,122 & 0,034 & Significant \\
3 & Domicile Attitude $\leftarrow$ Public Facilities & 0,481 & 3,244 & 0,001 & Significant \\
4 & Domicile Decision $\leftarrow$ Security & 0,055 & 0,374 & 0,708 & Not Significant \\
5 & Domicile Decision $\leftarrow$ Cleanliness & 0,003 & 0,048 & 0,962 & Not Significant \\
6 & Domicile Decision $\leftarrow$ Public Facilities & 0,488 & 3,320 & 0,000 & Significant \\
7 & Domicile Decision $\leftarrow$ Attitude & 0,349 & 2,537 & 0,011 & Significant \\
\hline
\end{tabular}

The results of the analysis are by using probability values with significant criteria, if $\mathrm{P}$ $<0.05$ and for testing with table $=1.960$, the results are : (1) Security has a positive and significant effect on the attitude of domicile. (2) Cleanliness has a positive and significant effect on domicile attitudes (3) Public facilities have a positive and significant effect on attitudes of domicile 4) Security has a positive and not significant effect on domicile decisions in Satelit city (5) Cleanliness positive and not significant to the decision of domicile in Satelit city. (6) Public facilities have a positive and significant effect on the decision of domicile in Satelit city. (7) The domicile attitude has a positive and significant effect on the decision of domicile in Satelit city.

Hypothesis test results above, shows that there are five hypotheses exist accepted and the two are not accepted can be seen from the critical ratio and probability are:

1) Security influence on the attitude of domicile. The calculation result significantly with $\mathrm{CR}=2.277 \geq 1.960$ and $\mathrm{P}=0.023 \leq 0.05$. The hypothesis $(\mathrm{H}-1)$ of security has a positive and significant effect on the attitude of domicile. It means that the security of a city influences a person's attitude in determining a place to live. A safe environment will make residents safe and calm in leading life in that place. Security for families, wealth and shelter is a necessity that must be fulfilled in order to live a happy life. Because every partner will build a family without fear around the place of residence such as violence, robbery, etc. 
2) Cleanliness effect on the attitude of domicile. The result of the calculation shows significantly to the value of $\mathrm{CR}=2.122 \geq 1.960$ and $\mathrm{P}=0.034 \leq 0.05$. The hygiene $(\mathrm{H}-2)$ hypothesis has a positive and significant effect on domicile attitudes. One aspect that can influence the attitude of people choosing domicile is the cleanliness of the city. Cleanliness is related to the elements of health, pollution, and odor, the ideal place to live is that which is free from aspects that interfere with human health. Many developers do a neat layout, residents lifestyle according to the rules of the float, so that cleanliness can be controlled properly. The concept of a residence does not need to be too broad, but synergy and harmony with the natural environment are integrated, for example, adequate road area, public facilities, and social facilities are available.

3) Public facilities influence the attitude of domicile. The results show a significant value of $\mathrm{CR}=3.244 \geq 1.960$ and $\mathrm{P}=0.001 \leq 0.05$. The hypothesis $(\mathrm{H}-3)$ of public facilities has a positive and significant effect on the attitude of domicile. The existence of a very densely populated metropolitan city, the Satelit city will be an alternative choice because the facilities needed are not far from the big cities. A Satelit city will try to fulfill public facilities such as schools, hospitals, and markets, etc. With adequate infrastructure, residents will not go to big cities, but they will use the facilities in Satelit city. Public facilities will strengthen the attitude of a person to live if the interests of citizens are fulfilled.

4) Security affects the decision to domicile in Satelit city. The calculation results show no significant value with $C R=0,374 \leq 1,960$ and $\mathrm{P}=0.708 \geq 0.05$. The hypothesis (H-4) of security has a positive and not significant effect on the decision of domicile in Satelit city. Everyone who will live in an area does not take into account security, in general, that city. The sense of security that is needed is the security of the environment in which they live, each person realizes that security is often unexpectedly disturbed. In deciding to choose a domicile, security aspects are considered but not the most important.

5) Cleanliness influence on the decision of domicile in Satelit city. The calculation results show no significance with the value $\mathrm{CR}=0.048 \leq 1.960$ and $\mathrm{P}=0.962 \geq 0.05$. Hypothesis (H-5) hygiene positive effect but not significant to the decision of domicile in Satelit city. The hygiene aspect becomes a consideration in determining people choose to live in a city because it is related to the quality of health. But it is not an absolute requirement, because the city is clean and beautiful, it means that everyone is not the same in per scales for domicile. A clean city is the necessity of every resident since become the pride of the city's population and the behavior of immigrants will participate maintain hygiene has been implemented.

6) Public facilities impact on the decision of domicile in Satelit city. The calculation result significantly with the value $C R=3.320 \geq 1.960$ and $P=0.000 \leq 0.05$. Means that the hypothesis (H-6) public facilities affect positively and significantly to the domicile decision in Satelit city. In deciding to stay in an area, public facilities need to be taken seriously, because everyone has the necessity to live and settle in the city. Adequate school facilities make people living in the city because it relates to the education of their children and other facilities that need the equivalent of a metropolitan city.

7) The domicile attitude affects the decision to domicile in Satelit city. The results of calculations significantly to the value of $C R=2.537 \geq 1.960$ and $\mathrm{P}=0.011 \leq 0.05$. Hypothesis (H-7) attitude domicile affects positively and significantly to the domicile decision in Satelit city. A person's attitude is influenced by many factors that will make a decision. The main aspect will be to strengthen people's attitudes to be positive, so they can take actions that are concrete and profitable for that person. It means that attitude 
will be real action if there is an external stimulus in a positive form and is able to fulfill people needs.

\section{B. Discussion}

a. Security has an effect on attitude

Security in one area will make the attitude of the people who tend to be positive. A variety of good information about security in a city will get a strong response from people who are considering determining the location of residence. An environment that is both manic and disciplined will strengthen people's attitudes in making decisions. Safe from crime, the district will become guidelines is to determine the attitude of a person to live in Satelit city. When the criminality aspect was severe, then people would be so apathetic attitude of the city, although other aspects are promising.

The state should ensure the environmental safety of all forms that create discomfort in the population congestion, noise, and violence. Maintaining environmental interest is not only the responsibility of the government, but the residents must have a big contribution because problems often arise from certain residents. Diversity is inevitable because our country is originated of differences in ethnicity, race, religion so that it must be maintained is unity and harmony so that violence does not occur. Satelit city is the next option after the metropolis, so the migration happens because in the city it has facilities that resemble big cities. The migration is not only residents who move to certain places, but entrepreneurs participate to be closer to their customers. So that congestion is unavoidable in Satelit city, so the security role is needed to regulate not to get people trapped in traffic.

Residents wish will be safe from the possibility of political or social strife that could harm the environment. Togetherness indifference must be instilled in every resident so that security remains conducive. Differences in political choice should not be the cause of intercommunity violence. Unemployment problems can lead to social insecurity, to deal with this problem the government must be sensitive and entrepreneurs need to help to solve it, so that crime does not occur which greatly disrupts people's lives. Feeling safe in an environment will feel comfortable for residents to live in that environment. Good security always increases the productivity of the population, because they feel no disruption in carrying out activities at any time.

The quality of the resident's security can affect comfort and well-being (Merrilees et al., 2009). Safety has a positive influence on the City Brand Attitude so that cities that are considered safe will get a City Brand assessment of a positive attitude from the community (Merrilees et al., 2009). This result is in line with the findings of Merrilees et al. (2013) that safety has a positive and significant influence on attitudes. The influence of security factors and people's attitudes on a city tends to lead to significant phenomena. The results of this study indicate that security has a strong function for the residents in determining its attitude, meaning that the residents evaluate the security aspects in the city of Sidoarjo when it is safe they convince themselves that one day they will make a decision to settle in Satelit city of Sidoarjo District.

\section{b. Cleanliness has an effect on attitude}

Clean and Green are activities that care about the environment, a learning platform to change the mindset of the citizens of Satelit city and residents behavior to increase awareness and participation in creating environmental sustainability. Q: What Knowledge society regarding waste management with the 3R (Reduce, Reuse, Recycle) in order to not removed households waste, then it needs to be used for good purposes and valuable economically. 
Organic waste is processed as fertilizer and non-organic waste can be used as crafts, recycling through waste banks managed well.

To change the environment begins with the neighborhood, then when the smallest area has realized the importance of a clean, neat, green, healthy, beautiful and comfortable environment, so that the entire city will be clean and green also. The role of the government to provide assistance and socialization to the community about city cleanliness is very important. Many big cities conduct hygiene competitions to foster awareness of clean behavior. The competition and mentoring activities aim to change the mindset of the community so that they can change environmental conditions in a real and continuous way. Residents of Sidoarjo as a Satelit city seeks to reduce waste and can overcome the problem of waste so that it can make as a clean Sidoarjo, East Java and Indonesia. Forming a mental revolution about hygiene awareness is the responsibility of Satelit city stakeholders.

A healthy environment is started from good air circulation, occurred in the area around the residents. A way to provide a green buffer area utilizes a park that is believed to provide clean air. The park has a function to reduce the noise of motorized vehicles and filter the air coming into the house will be fresher and better quality. For that, creating a healthy environment starts from yourself so that the health is in top condition, so it is not susceptible to disease. Clean air means pollution-free, then many trees grow in the environment will create fresh air circulation. Clean and good air is containing oxygen because humans really need it every time they breathe.

The cities that have high congestion levels will have an impact on air quality. People often dispose of trash because they have difficulty to find trash bins. The behavior of many riders and passengers throw garbage from their vehicles make the trash can fly to any places or ditches that can results flood. The city does not have hygiene problems caused by traffic, because the local government has clear regulations and is strictly enforced.

The physical conditions of the environment are assessed from aspects of physical cleanliness and pollution free (Merrilees et al., 2009). The results of this study are not in accordance with the findings of Merrilees et al. (2013) that in this variable of cleanliness have a positive influence and significant on the attitude of residents of Satelit city. Research objects can get different results because there is an influence on one's education level. Whereas Satelit city like residents Sidoarjo feel issues of cleanliness are important because there are many people who migrate from metropolitan cities, so their expectations are very high on clean and green. A positive human attitude to cleanliness, then an effort from the government or developer must pay attention to environmental cleanliness so that residents are more likely to live in the city.

\section{c. Public facilities have an effect on attitudes}

Health facilities are the basic need of people, the government has to give more attention to safeguarding public health. Health is an indicator of living conditions in establishing people as a healthy nation. Public facilities in Satelit city always do refinement to enhance health services for the people that implemented optimally. The existence of the BPJS is a health insurance service to improve people's access to the health facility. Satelit city seeks to provide hospitals, community health center, medical centers so that people can seek the health services in their own city. Health services must be improved optimally so that citizens feel cared for by the local government.

Facilities and infrastructure are supporting elements of the success of the public service process. Elements of educational facilities need extensive land so that development becomes easier, having adequate buildings so that the teaching and learning process runs optimally, the equipment must be available so that the implementation of quality learning 
and school appliance to support the implementation of student activities. School management needs to be done either through a management function including, planning, provision, inventory, archiving, arranging, maintenance, shortening, and supervision. Buffer city is trying to prepare schools quality as equal to metropolitan cities. The government wants to provide good service to its citizens, so the children who go to school do not need to leave the city. The satisfaction of the citizens of the city will be guaranteed by the government because it is an obligation to have citizens who have the quality of education.

The usage of private vehicles is better but not necessarily guaranteed, because of the level of congestion. Cities with high traffic density, transportation management continues to be improved while widening the road. Public transportation is transport services to passengers with mass travel system and there is a cost burden on every trip to the destination. Public transportation greatly helps population mobility, both school children, workers, and freight transport. Sidoarjo City as a buffer city has so many public facilities such as airports, national terminals are located in that location because it is very practical for users, especially residents of the metropolitan city. Health care, education, home for the elderly, and housing services for residents (Santos, Martins, and Brito, 2007).

The results of previous studies conducted in Logan City and Ipswich Australia, that public facilities variables have a positive and significant influence on influencing the attitude of Satelit city residents (Merrilees et al., 2013). Almost all humans in the world have the same attitude about the needs of public facilities provided by the government. Government services and residents attitude in Satelit city tend to have a relationship become true because citizens can not provide personally like schools and hospitals. The availability of adequate public facilities in a city will make the people not worried because they don't flock to schools in the metropolitan city and don't seek health care in a big city. For this reason, the role of the government is very strategic in providing the needs of the residents.

\section{d. Security has an effect on the domicile decision}

The decision of people in determining the domicile influences many aspects, which are, security, cleanliness, public facilities, purchasing power, infrastructure, and transportation. A sense of security for citizens is a necessity so that life feels safe, peaceful and comfortable. The secure environment from crime becomes hope to every resident because if frequent violence arises then people will not feel at home in those places. In general, security needs to be done by the citizens, but it is not impossible because the state has a responsibility for the security of its citizens.

A safe place to live is everyone's wish so that they can carry out activities optimally, so productivity will increase. Residents awareness is needed by storing goods that are owned properly and correctly. The wickedness will arise because of precious objects that are not kept properly, there will be theft that harms the citizens themselves. For the residents, participation in security is very necessary so that the environment becomes secure and always follows the regulations in the region. A safe neighborhood will increase activities both economically and socially so that there are no gaps in the residents.

The results of this study indicate that security has a positive effect but is not significant in the domicile decision. This means that a safety factor for the residents is needed so that activities in life can without worry and interference. But the residents do not want strict security rules, but the security function still exists, which is carried out by the residents and the government through security units or the police as the people protector. The economy will develop if people feel safe in carrying out their business activities. Cities that often arise conflicts between residents, will bring uncomfortable living so they migrate to other places. 
The level of security of people influences comfort and well-being (Merrilees et al., 2009). The results of the research conducted means that security can bring citizens to be prosperous because they feel calm in carrying out activities in the form of business because there is nothing to disturb. The intention to live will measure can be seen from the intention of the residents to live in a city including retirement and settling in the city (Merrilees et al., 2013). The results of the study support those who say that security has a positive but not significant effect because people believe that there is someone protecting the country. Because the government must be standing by at all times to protect and protect all its citizens so that there will be no violence in the family sphere or the existence of crimes.

e. Cleanliness has an effect on domicile decision

Clean and Green is the dream of every city resident because it is always related to health. Cleanliness is related to air pollution, slums, and irregularities in a city, while green is a provider of clean air, beauty, and coolness of the city. Satelit city as a buffer area for metropolitan cities has similar problems with cleanliness and reforestation because housing grows and develops in various corners of the city. City planning must be done by considering green land to maintain air circulation so that people get good and clean oxygen.

Satelit city such as Sidoarjo must maintain environmental hygiene by socializing awareness of disposing of waste at their place, if not regulated, residents will dispose of waste as they please. Unregulated waste will scatter and disrupt the flow of water, causing flooding, resulting in disease. Counseling about awareness of waste utilization needs to be done early on in the children of students so that they understand the dangers of waste to health if not managed properly.

In order for cool and shady air, the government through the sanitation department needs to plant and maintain protected trees that will be a place for residents to shelter. Green space is needed so that the city looks beautiful and clean, so the residents will be happy and decide to stay in the city. Buffer city will be the choice of residence after the metropolitan city and often people do not think too much about cleanliness in a strict manner, but there are government concerns to maintain cleanliness. The decision to stay in one city is indeed a lot of consideration but they have to choose the most profitable for the community, for example, public facilities such as quality schools, adequate hospitals, and smooth transportation.

Cleanliness is always related to the physical conditions of the environment which are assessed from aspects of physical cleanliness and pollution-free (Merrilees et al., 2009). The physical environment can be seen from structuring the construction of housing and infrastructure in the city, while physical cleanliness is the provision of trash bins and utilization equipment. Waste management is a form of activity so that continuous cleanliness of the environment is always clean. A clean city gives the impression to the wider community that the population has a concern for health and beauty. The cleaner the city, the higher the resident's pretension to stay. Because a clean city makes people comfortable and avoids disease. The clean city teaches the population to participate in maintaining the cleanliness, so high population wishes to remain in the city for a long time. Every resident has high hopes for health and life expectancy will be longer.

f. Public service has an effect on domicile decision

Many people believe that choosing a place to stay in a city that has all and adequate public facilities. Satelit city accommodates many people who migrate from metropolitan cities because they are close to workplaces or school children. The existence of a buffer city is very helpful for population density and the development of settlements that occur in large cities such as Surabaya. Public services quality could make the public interested to stay in Satelit 
city. The availability of modern schools and quality will be the attraction to people who decided to settle in Sidoarjo as a Satelit city. Other public facilities are also available well so that the mobility of the residents of the buffer city no need to looking for the metropolitan city.

Public services are the government's obligation to provide people with the right to live in the city. Buffer city should have adequate transportation services so that people are not stuck in traffic on the road. The role of the state in presenting quality schools and adequate health facilities is very much awaited because citizens can carry out efficiency in spending on family interests. A person's decision to choose a place of residence depends on existing public facilities, so they are more calm and comfortable and more productive in carrying out life activities.

Health facilities, education, homes for the elderly, and housing services for residents (Santos, Martins, and Brito, 2007). The higher of government service for the needs of the citizens, the greater the decision to live in the city. Every resident does not want to straighten when going the government services so that residents will stay in the city. This research showed significant and positive results as well as provide support for government and residents services to stay. It means that public facilities have an influence on the residents in deciding to live in a Satelit city such as Sidoarjo district.

\section{g. Domicile attitude has an effect on domicile decision}

The process of forming someone's attitude is a lot of factors that affect both the personal internal and external, depending on the stimulus to the person. The attitude that comes from personal itself still needs some accurate information, if it shows a positive tendency, then that person will decide to live in a city. External factors can affect people because they have the representation of various information who will try to live in certain areas. For someone who has a lot of information about the location of housing and makes them interested, they will make the decision to stay.

Assessing areas that are highly dependent on public facilities, security and cleanliness are the main aspects, but other aspects are also considered as support. Cities that have full public facilities can make people interested in living in that place. People have a positive attitude to the city, so they must try to get a place to live in a Satelit city. People who live in a buffer city like Sidoarjo, feel happy because it is near the city of Metropolis, so all needs can be met.

The attitude of the residents in the city become true, reputation and pride will occur in the city (Merrilees et al., 2009). The residents' attitude on the city has a positive effect on their intention to live in the city (Merrilees et al. (2013). It means residents' attitude has a positive and significant effect on domicile decision to live in Satelit city. People attitude influenced many aspects of life. People really need health, education and good interactions with others. Feeling safe in life to do activities well maintained, so that the worry will disappear. A clean residential environment is indeed the dream of everyone as a local resident because it is far from pollution and slums and the quality of life is guaranteed.

\section{Conclusion}

Based on the results of the analysis of each variable and the hypothesis test can be concluded as follows:

1. Security can be used as a consideration for people's attitudes to the process of determining domicile. For caretakers, it is better to show a sense of security in a housing complex that has been or will be built. Security aspects can attract migrants to settle in that area because they believe they can build a calm and peaceful family life. The quality 
of security is not much different from a metropolitan city that is very strict and conducive to its environment.

2. Cleanliness makes people's attitudes tend to positive, so clean and green will maintain a positive attitude for the people who will live in Satelit city. A clean environment will shape good attitudes, it will bring the mindset of someone affected in positive conditions. The tendency of residents to want to live in a clean area is very high so that developers are offering prospective home buyers about cleanliness. Clean air is always related to a clean environment because the source of the pollution spreader is from waste.

3. Public facilities will bring a good attitude of people because as the basis for determining the location to live. Satelit city governments should provide adequate public facilities that are not much different from big cities. Such as education, health, sports and the place for the elderly, so that the residents of the city do not take advantage of the facilities owned by the metropolitan city. Therefore, improving the quality of services to the population can be perceived well by its own citizens.

4. People attitude on security can be the decision to stay in Satelit city, even though they are not too sure about the implementation of security in the area. Sidoarjo is a buffer city that can collaborate on security with the metropolitan city to deal with various kinds of violence so that it can be suppressed. To give a sense of security, the security forces always patrol all areas with the potential crime.

5. Some people say that clean is not too decisive in choosing to live in a city, but there must be someone who handles it so that it doesn't happen in a slum city. Many residents domiciled in the areas that are not so clean but still have a great hope that area could be clean and green. Even though the domicile often craves a clean environment, because it is related to air quality.

6. A buffer city like Sidoarjo should have good facilities so that the population no longer looks for schools quality in big cities. Districts who care about the provision of public facilities such as hospitals, health centers, and school quality, it will be able to increase revenue because they all residents of the transaction in the city.

7. The process of people attitudes has a strong carrying capacity for someone to make important decisions in his life, among others, to determine the place of residence in one city with a variety of mature considerations. Deciding to domicile in an area has many influencing factors but must choose the most important aspects or be able to convince yourself, so that it will be easy to achieve his life goals.

\section{Suggestion}

Based on the results of the analysis carried out accompanied by in-depth discussion, there are several suggestions, namely :

1. Someone who decides to domicile in Satelit city should consider the available public facilities as a service to the residents. Although there are many aspects that need to be information for us, needing to convince you to be able to build a family is more comfortable and calm compared to its place of origin and can be more productive.

2. For developers who provide housing, it is necessary to pay attention to the elements needed by residents. Security, clean and provided a wide range of facilities, will strengthen someone in the decision to choose to stay in Satelit city.

\section{References}

Aaker A, Kumar, V., \& Day, G.S. (2001). Marketing Research, Seventh edition. New York: John Wiley \& Sons Inc. 
Dharmmesta, B.S., \& Handoko, T. Hani. (2012). Manajemen Pemasaran Analisis Perilaku Konsumen. Edisi Pertama. Yogyakarta: BPFE.

Dharmmesta, B.S., \& Irawan. (2008). Manajemen Pemasaran Modern. Yogyakarta: Liberty.

Engel, J. et al. (2004). Consumer Behaviour. Mason: Permissions Department, Thomson Business and Economics.

Ferdinand, A. (2013). Metode Penelitian Manajemen, Edisi 4. Semarang: BP Universitas Diponegoro.

Fishbein, M., \& Ajzen, I. (2006). Belief, Attitude, Intention, and Behavior: An introduction to theory and research.

Ghozali, I. (2013). Model persamaan Struktural Konsep \& Aplikasi. Cetakan V. Semarang: BP Universitas Diponegoro.

Kerlinger, Fred, N. (1990). Foundations of behavior research. Third Edition. Yogyakarta: Gajah Mada University.

Kotler, P. \& Gary, A. (2014). Principle of Marketing. 15th edition. New Jersey: Pearson Prentice Hall.

Kotler, P. \& Keller, K.L. (2013). Marketing Management. Global Edition. England: Pearson Education Limited.

Merrilees, M., and Herington. (2013). City Branding: A Facilitating Framework for Stressed Satellite Cities. Elsevier, 66(1), 37-44.

Moenir. (2002). Manajemen Pelayanan Umum di Indonesia. Jakarta: Bumi Aksara.

Nana, S.S. (2009). Landasan Psikologi Proses Pendidikan. Bandung: Remaja Rosdakarya.

Secord, P.F., \& Backman, C.W. (1964). Social Psychology. Tokyo: McGraw-hill.

Stoner James, A.F. (1996). Manajemen. Edisi Bahasa Indonesia. Jakarta: Prenhallindo.

Sugiyono. (2010). Metode Penelitian Bisnis. Bandung: Alfabeta.

Tarwoto \& Wartonah. (2010). Kebutuhan Dasar manusia dan Proses Keperawatan. Jakarta: Salemba Medika.

UU Nomor 36 Tahun 2009 tentang Kesehatan, Kementrian Kesehatan Republik Indonesia. 